\title{
Land Rights, Industrialization, and Urbanization: China in Comparative Context
}

\author{
Susan H. Whiting ${ }^{1}$ (D)
}

Accepted: 19 January 2022 / Published online: 28 February 2022

(c) Journal of Chinese Political Science/Association of Chinese Political Studies 2022

\begin{abstract}
What do studies of land rights in China contribute to the broader discipline of political science? First, the Chinese case challenges orthodox theories of secure, private property rights as a prerequisite for growth and sheds light on the distinctly fiscal roots of urban bias, a phenomenon pervasive in countries making the transition from agriculture to industry. Second, studies of land grabbing in the Chinese case provide a basis for comparisons of state-society relations in authoritarian vs. democratic regimes. While democratic institutions create more openings for aggrieved actors to organize and shape policy, ordinary citizens in both authoritarian and democratic regimes use protest in order to capture a greater share of rents from land. Third, land grabbing exacerbates inequalities; research on the Chinese case in comparative context shows that exclusionary modes of land ownership and limits on full social and political citizenship are mutually reinforcing across all types of regimes.
\end{abstract}

Keywords Land · Property rights · Law · Urban bias · Rural · Urbanization · Industrialization · Agribusiness · Authoritarianism · Democracy · Gender · Citizenship $\cdot$ Growth $\cdot$ Development $\cdot$ Regime type

The phenomenon of land grabbing ${ }^{1}$ for urbanization, industrialization, and agribusiness is prominent not only in China but around the world. Studies and debates focusing on land rights in China contribute three important takeaways for the discipline of political science. ${ }^{2}$ First, the Chinese case challenges orthodox theories of secure, private property rights as a prerequisite for growth and sheds light on the

\footnotetext{
1 The term land grabbing has its origins in Marx, Capital, and is associated with primitive accumulation.

2 While the broader literature is highly interdisciplinary and international, with significant contributions by economists, sociologists, geographers, anthropologists, urban planners, and legal scholars in multiple languages, here, the focus is on the work of political scientists published in English.
}

Susan H. Whiting

swhiting@uw.edu

1 University of Washington, Seattle, WA, USA 
distinctly fiscal roots of urban bias, a practice pervasive in countries making the transition from agriculture to industry. China's experience further shows that the state's urban bias intensifies economic risk by distorting market forces. Second, studies of land grabbing in China highlight a similar role for protest in both authoritarian and democratic regimes. While, by comparison, democratic institutions create more openings for aggrieved actors to organize, shape policy, and pursue legal remedies, ordinary citizens in authoritarian and democratic regimes alike use protest in order to capture a greater share of rents from land. Third, land grabbing exacerbates inequality. The Chinese case sheds new light on the exclusionary nature of land rights in contemporary and historical cases, exposing the link between unequal access to land and incomplete social and political citizenship. While China's "dual society" is divided between urban and rural citizens, divisions elsewhere reflect race, caste, and gender. ${ }^{3}$ This essay reviews each of these three points in turn, highlighting China's contribution to comparative theory.

\section{Land Rights in the Political Economy of Development}

\section{Land Rights Insecurity}

China's rapid development over the past half century challenges a core tenet of political economy theory. Rural land rights are insecure, while the economy has experienced sustained economic growth. The "rights hypothesis" holds that secure property rights are a prerequisite for economic growth [51]. Clarke, Murrell and Whiting ([18]:376) argue that "the rights hypothesis, as traditionally interpreted, provides little explanatory power for China." On the one hand, consistent with mainstream theory, major policy initiatives like the household responsibility system (HRS) place more of the bundle of rights over land in the hands of households, with positive effects on agricultural output and productivity. On the other hand, the land rights of rural households remain insecure, especially due to state land takings. Indeed, the state plays a prominent role in re-assigning land rights from rural households to new end-users to develop infrastructure, industry, and urban real estate [88].

What the literature has missed is the role of the state in reassigning of land rights from lower-value, agricultural use to higher-value, urban, industrial uses as part of the economic development process [88]. State intervention reduces a variety of transaction costs that slow the transition to a more productive, technologically advanced economy. Land-rights holders in the old economy who lack the skillset to compete or the political power to benefit in the new technological environment resist commodifying their land. The Chinese state uses its political power, formalized in law, to take land for state-directed urbanization and industrialization. In comparison, Levien (2011:455) cites reports that "farmers refusing to part with their land might become the largest obstacle to India's economic growth" and highlights the multi-faceted struggle over land between the state, developers, and rural elites on the

\footnotetext{
3 The division between Han and non-Han is salient to land but under-studied by political scientists.
} 
one hand and dispossessed farmers on the other. State reassignment of land rights to accommodate technological change may be more or less market-conforming. Administrative targets are more common, and market-based signals are more muted in contemporary China than in India today, resulting in less efficient land use in the Chinese case [90]. Nevertheless, the Chinese case sheds light on a more complex relationship between land rights and economic development than mainstream theory has recognized.

\section{Urban Bias}

Governance of land in China reflects a pattern of urban bias. The essence of urban bias is state action to generate and capture rents by extracting resources from the rural sector at artificially low prices to achieve above-market returns in the urban sector. Drawing on research in South Asia and Africa, Lipton [45] refers to this price structure as price twists, while Naughton [50], concentrating on China, employs the metaphor of price scissors. More broadly, urban bias directs resources and focuses public spending in urban as opposed to rural communities [35]. Looney ([46]:43), referring to a preference for industry and for "applying industrial principles to agriculture and urban models of residential life to villages," introduces an overly expansive definition of urban bias that departs significantly from the standard. In less ideational and more material terms, urban bias in China reenacts patterns of the planned economy and is most visible in the contemporary policy and legal regimes governing land and labor.

There is debate over whether urban bias still exists. Classic accounts of urban bias include Bates [2], who examines the monopsony power of agricultural marketing boards in African states. This power allowed them to purchase agricultural commodities at below-market prices for supply to the urban market, generating taxable rents in the urban sector and supporting revenue extraction by the state. Under China's Mao-era planned economy, the state exercised similar monopsony power over grain, cotton, and other agricultural commodities [53], keeping costs to the urban sector low and generating rents controlled by the state [50]. I argue that, land itself, extracted from the rural sector at below-market prices, has become the most important reflection of urban bias, challenging Wallace's ([79]: 122,185) claim that the Chinese state has moved away from urban bias through increasingly pro-rural policies [84].

With the perpetuation of the dual land regime, China has shifted urban bias to the commodity of land itself. The state holds a de jure near-monopoly on the conversion of rural to urban land. ${ }^{4}$ Statutory compensation to villagers for state takings of rural

\footnotetext{
${ }^{4}$ Pilot reforms formalized by the State Council in 2015 led to the 2019 revision of the Land Management Law, which permits the direct sale of rural collective construction land into the urban primary land market, thereby ending the state's complete legal monopoly on conversion of rural to urban land. However, rural collective construction land (land formerly used by township- and village-enterprises, e.g.) is a small percentage of total rural land, and the reform does little to weaken the state's monopoly power [88].
} 
land is tied to the use-value of the land in agriculture, officially justified in terms of meeting villagers' subsistence needs and well-being-not in terms of market value $[57,85] .{ }^{5}$ While land grabbing and urban bias are global phenomena, these institutional features make the Chinese case more extreme.

\section{Fiscal Roots of Urban Bias}

Comparativists have called for better data to clarify the origins of urban bias [35; 49], and studies of the Chinese case advance comparative theory by specifying the specific, fiscal roots of urban bias. The phenomenon of "land public finance (tudi caizheng 土地财政)” has been a major focus of political scientists working on China [54, 70, 73, 81]. The 1994 tax-sharing system (fenshuizhi 分税制), which centralized control over fiscal revenue without changing expenditure responsibilities, created a fiscal gap for local governments. They have filled this gap in large part with extra-budgetary revenues from land conveyance fees. Pei ([56]: 55) claims that leaving land revenue to local authorities was an intentional inducement for local governments to accept the tax-sharing system, but the claim of intentionality lacks supporting evidence.

In the Chinese case, local governments' near monopoly on rural-to-urban land conversion allocates rents in particular ways. Local governments generate significant non-tax revenues by selling land-use rights acquired at low cost through state land takings into the urban, primary land market for real estate and related development at high prices [29]. Land conveyance fees were equivalent to less than ten percent of total fiscal revenue in 2000, but they grew to a high of 46 percent in 2020 [86]. This jump reflects even greater reliance on land conversion to fund local government in the context of growth shocks like the global financial crisis and covid-19 pandemic.

Research on land public finance sheds light on larger political dynamics [92]. Failure over the past decade to legislate a property tax, suggests that local governments and the urban middle class are powerful constituencies for the current regime in China. A property tax, called for in the decision of the 2013 Third Plenum agenda on deepening reform, could replace land sales as a revenue source and place local governments on a sounder fiscal footing [86]. However, a comprehensive property tax would cut into lucrative rents, as well as hit the wealth of urban homeowners [24]. ${ }^{6}$ The Chinese case highlights the political underpinnings of urban bias [2], underdeveloped in the recent comparative literature.

\footnotetext{
5 Scholars' description of rural China as having a subsistence economy is less accurate. Chuang ([17]: 16), for example, writes that commodification of rural labor in China coexists "with support of a rural subsistence economy (emphasis added)." By contrast, "off-farm labour opportunities are correlated with the renting out of land by households ([5]: 1044)." Rural migrant workers who hold rural hukou and land in the village retain ties to rural status and citizenship but not to subsistence farming [74]. Anthropologists define a subsistence farm family as one that grows most of what it consumes and consumes most of what it grows (Harrell 2021, personal communication). Not only is land increasingly commodified, but so are most agricultural products and consumer goods.

6 Narrowly targeted property tax pilots began in Shanghai and Chongqing in 2011; new pilot programs were authorized in 2021, suggesting that implementation of a property tax is still some years away.
} 
Local governments also use their control over land supply to promote industry by providing land for industrial parks at low prices. Land conversions contribute to local tax revenues directly, through land-use taxes, and indirectly, through taxes paid by firms [83]. The formal tax system relies more on taxes paid by firms than by individuals, and cheap land is one tool to attract investment capital and recruit firms to the local economy ([73, 81]:139). Levien's [40] work on land acquisition in India shows that Indian policymakers consciously studied China's experience using land to develop industrial parks and special economic zones.

Land-backed local government debt intensifies urban bias [8, 65, 87]. The pace at which urban infrastructure (including roads, bridges, rail, and other transport as well as public utilities like water and sewage) has expanded in China is "astonishing, all the more so when compared to the infrastructure problems plaguing many developing countries ([78]:686)." In China's case, the push to develop urban infrastructure is accelerated by the combination of mandates set for local government via the cadre evaluation system, the dual-land-rights regime, and the state-dominated financial sector. Local governments have "mapped out a 'land-infrastructure-leverage' strategy... Improvements in infrastructure are used to attract outside investments (including FDI [foreign direct investment]). The strategy is driven by debt leveraging ([78]:688)." Beijing authorized local governments to set up local-governmentfinancing vehicles (LGFVs), which-unlike local governments themselves-can borrow from banks, using land acquired by local governments as collateral.

\section{Political and Economic Risks of Urban Bias}

While this strategy existed prior to the 2008 global financial crisis, the central government's stimulus response spurred local governments to increase their reliance on land-backed LGFVs, exacerbating risk and misallocation in China's political economy. Shih [65] provides estimates of the level of local government indebtedness and emphasizes the risks of excessive debt. Because land values can be volatile and tax revenues are limited, resources may not be adequate to enable repayment. Whiting, Abramson, Yuan and Harrell [87] report that even village-level authorities take on land-backed debt to finance the concentration of village housing in new residential settlements (jizhong juzhu 集中居住), designed to free up former residential land for land quota trading. ${ }^{7}$ In the private economy, real estate developers like Evergrande take advantage of this system to build commercial empires with land-backed debtmuch of it from state-owned commercial banks, fueling a possible housing bubble and contributing to the phenomenon of "ghost cities" $[68,86]$.

China's continued reliance on land for financing urbanization and subsidizing industrialization creates a range of additional policy concerns-from predation to environmental degradation. Cai, Fan, Ye, and Zhang ([8]:2331) find that "more indebted local governments take a more extractive approach by paying land-losing

\footnotetext{
${ }^{7}$ Land quota trading delinks "the location of new construction from the location where the land quota was generated. ...Local governments generate land quotas by concentrating rural housing into denser settlements and reclaiming the vacated land for agricultural use ([87]: 272)."
} 
villagers less compensation." They characterize local authorities as both developmental and predatory. Local authorities cause unrest in the process of relocating villagers and struggling to repay obligations [54]. Finally, the introduction of scale farming and the practice of concentrating rural housing are associated with monocropping and the elimination of trees and green space that typically surround more traditional rural housing; these practices reduce ecological diversity, undermining the resilience of existing ecosystems [87]. The serious ecological aspects of land grabbing have received little attention in the China and comparative literatures.

Rents are associated with corruption in China as elsewhere [27, 71], although the comparative relevance of the Chinese case is underdeveloped. Reports suggest that corruption in China's primary land market is widespread [11]. Pei ([56]: 50) characterizes the real estate sector as a "hotbed of crony capitalism in China," since it has the potential to generate "most of its profits from obtaining cheap land." He compares China with other post-communist cases, focusing on incomplete reform of property rights and decentralization, although this comparative framework is not carried through in his empirical analysis of land and mining. Moreover, Pei ([56]:19) argues that "crony capitalism in noncommunist societies... [is] qualitatively different." This claim misses the connection between state officials and private developers in allocating land and mining rights in cases like Mexico and India, specifically, and throughout Asia, Africa, and Latin America, more broadly [28].

Land-related political corruption has received comparatively more attention in the scholarly literature on China. Roughly one quarter of China's state corruption cases in one sample from the first decade of the twenty-first century were related to the primary urban land market [26]. "Villages also engage in informal [illegal] takings outside the regulatory purview of local government land bureaus [5]." Village cadres and, to a lesser extent, individual households engage in illegal conversion in order to capture a share of the rents, the majority of which accrue to local governments and those well-connected to them [69;71]. Village cadres and households are excluded from the state's formal monopoly on land conversion, and their ability to capture officially generated rents are further limited by the "red line" policy, which mandates that a minimum of 1.8 billion mu (120 million hectares) of arable land be maintained. Land takings are also associated with vote buying in village elections (Kennedy [38], Ma et al. [47]).

The study of land in China highlights the need for a more nuanced theory of property rights and economic growth. In addition, China's extreme case of urban bias reveals not only the fiscal roots of urban bias but also its political, economic, and environmental risks.

\section{Normative Implications: Accumulation by Dispossession}

A prominent strand of literature beyond the Chinese case draws on Marxist theory to examine the normative implications of land grabbing. Accumulation by dispossession, first elaborated by Harvey and Castells (see [37]) and introduced to the China field by geographers like Hsing [33], updates the Marxist notion of primitive accumulation in the context of advanced global capitalism and introduces normative 
concerns about the well-being of dispossessed classes $[28,40] .{ }^{8}$ Accumulation by dispossession is defined by the use of state power to uproot largely peasant populations, turning land and labor into commodities - a violent process in which they become subject to market forces and the power of state, private, and foreign capital.

While the dispossession frame dominates the comparative literature, China fits imperfectly in this body of theorizing. The Chinese experience suggests that dispossession is not unique to full capitalism and does not necessarily entail a transition to private property rights. Sargeson [61] embraces the notion of dispossession and argues that violence is a constitutive part of a highly inegalitarian development process in China. Zhan [91], by contrast, argues that China is different. She identifies three forms of accumulation without dispossession, including the development of collective township- and village-enterprises (TVEs), the resettlement of land-losing villagers in new urban housing with home ownership and urban benefits, and the retention of rural collective land rights by migrant laborers. The literature on unequal citizenship, reviewed below, echoes the normative critique of the Marxist literature.

The degree of village solidarity in the face of dispossession drives debate in both the Chinese and Indian cases. At the village level in China, leading cadres are popularly elected and notoriously Janus-faced, standing at the intersection of state and society. Sargeson [63] examines the relationship between collective land ownership and villagers' participation in self-government, measured in terms of deliberative decision making and leadership turnover in elections, and finds a positive relationship. While villagers are active in village self-governance, there is unresolved debate about whether, in the context of managing property rights over land, cadres serve the interests of the state [48], their familial networks [77], villagers [10], or themselves [93]. Kan [36] finds that "lineage loyalties and kinship networks can be activated both in facilitating land dispossession and in mobilising against it." Indian villages are similarly divided by caste and class, and Levien $(2011 ; 2021)$ calls for further study to explain instances of cross-class and cross-caste solidarity in resisting dispossession.

The comparative literature also addresses accumulation by dispossession in the agricultural sector, including land grabs by agri-business [1]. In China, the state plays a key role in the expansion of agri-business (both domestic and foreign) through maintenance of collective land ownership, promotion of large-scale agricultural investment, and consolidation of arable land. State subsidies have been adapted to promote larger agri-business instead of household farming in China [75] as elsewhere [28]. Village leaders have, in addition to consolidating residential land, mobilized and coerced households to contract arable land back to the village, reducing transaction costs for agri-businesses seeking large tracts [5]. These policies allocate valuable rents created by state intervention away from farm households.

\footnotetext{
${ }^{8}$ Rithmire [59] highlights the access by foreign capital to land in Dalian. With a focus on the urban sector, she does not employ the concept of accumulation by dispossession. Nevertheless, Rithmire suggests that political bargains over land entail a moral commitment to disadvantaged groups. Sargeson ([62]: 168) disagrees, concluding that "winning actors obviously have failed to fulfill their moral obligations."
} 
Ideological debates about whether full privatization of rural land would better serve the interests of China's rural households swirled in the years leading up to the passage of the Property Law in 2007 and the thirtieth anniversary of the household responsibility system in 2008. Ong ([55]: 366) characterizes both China and India as implementing "neo-liberal doctrine" with respect to land. However, in China, land is owned by either the state or the village collective, many land transactions are not directly subject to market forces [5], and the party-state has effectively shielded land policy from the ideological debates over privatization, a core element of neo-liberalism [74]. Andreas, Kale, Levien, and Zhang ([1]: 1118) suggest that "the experience of India shows that private property rights would not obviate the pressure for large-scale land dispossession by the state." Nevertheless, they conclude that the absence of prior, thorough-going land reform, as in 1950s China, leaves landless farm laborers in India particularly disadvantaged in the face of dispossession.

\section{Regime Types and Land Grabs}

Land grabs provide a fruitful lens for comparing the effects of regime type. Comparisons between land rights in the two most populous countries in the world, China's authoritarian regime and India's democratic one, highlight the role of democratic institutions in providing institutional veto points to check land grabbing ([1, 60, 88]). The Chinese state has insulated land policy from a range of societal pressures, which are much more politically powerful in India. The latter is more open to citizen mobilization on both the policy formation and policy implementation fronts; in China's closed political system, by contrast, limited citizen mobilization is more focused on how state decisions are implemented and enforced. Protest plays a role in both systems [1, 40].

\section{Political Institutions}

Andreas et al. ([1]:1126) highlight India's "relative democratic openness" in comparison to China's authoritarianism. Most prominently, political party competition in India creates openings for political influence on the part of organized groups in civil society that shape policy. These groups were instrumental to the passage in 2013 of the Right to Fair Compensation and Transparency in Land Acquisition, Resettlement, and Rehabilitation Act (LARRA), which replaced the colonial era Land Acquisition Act and expanded procedural protections and access to compensation [40; 88]. Party competition also plays out in state-level politics. A diverse media landscape further amplifies the voices of civil-society activists. In comparison, China lacks party competition, organized groups fighting for land rights, and free media ([1]:1117). As a result, policy making is insulated from societal influence. 


\section{Protest}

Protest plays an important role in resisting land grabs, but, in the authoritarian case of China, debate exists over how common protest over land is. Part of the debate involves identifying meaningful metrics. Göbel (2019), using the Wickedonna dataset-hand collected from social media by activists Lu Yuyu and Li Tingyu between 2013 and 2016, claims that "protests against land grabs and evictions are less frequent than the literature on these issues suggests" and reports that rural land conflicts constitute only 12 percent of all collective action events. Zhang and Pan (2019) employ deep-learning algorithms to classify image and textual data from social media posts and put the share at 17 percent for the years 2010-2017. Focusing specifically on rural land, Brandt, Whiting, Zhang, and Zhang [5] employ a small but locally representative sample survey of households and villages to establish a baseline: between 1996 and 2011, sampled villages in Jiangsu experienced nearly five land changes per village, while those in Shaanxi experienced less than one land change per village on average. ${ }^{9}$ In the sample as a whole, "fully 35 percent of all land changes resulted in disputes involving households. ... Moreover, protest occurred in 55 per cent of all disputes ([5]:1045)." Thus, protests occurred in about one-fifth of all state- or village-initiated land changes.

Recent literature focuses not only on the incidence of protest but also its causes and effects. Scholars report precarity, inadequate compensation, violence, and violations of law and procedure as drivers of protest [5, 14, 32, 39]. Brandt et al. ([5]: 1047) show that protest was significantly more likely where land had "higher value," and households sought "to capture a share of that value."10 Repression influences not only occurrence of protest but also its ultimate effectiveness. Heurlin [30] argues that, at the local level, protest leads to policy concessions like provision of social insurance; by contrast, Göbel [25] claims that more intense protests and those that entail costly concessions in fiscally constrained regions are less likely to succeed. Deng and O'Brien [20] further identify "relational repression" as an effective tool of the local state to control protest impact. Finally, Tang and Côté [72] suggest that media coverage and positive media framing are associated with protest success. However, rural land disputes receive less frequent and less favorable coverage, limiting media impact (Zhang and Pan 2019). Additional data is needed to resolve these debates. In India, Levien and Upadhyay (2021:20) report that, "land acquisition protests can, and increasingly do, succeed in increasing compensation to farmers" and in halting land takings intended for private purposes.

\footnotetext{
${ }^{9}$ Land changes refer to changes in households' land rights, including state land takings, village-mediated transfer of land to new end-users, and village land reallocation.

${ }^{10}$ Brandt et al. ([5]: 1045) differentiate the institutionalized practice of petitioning and extra-institutional protest; Heurlin $[31,32]$ uses the institution of petitioning as a proxy for protest, while drawing a similar conclusion that resistance is more likely to occur where the value of land is higher.
} 


\section{Law and Justice}

The importance of land as a valuable asset for ordinary citizens spurs scholarly debate about fairness, justice, trust, and legitimacy in the context of land rights. Gibson ([23]: 714), writing on South Africa, identifies a complex mix of distributive and procedural justice claims for squatters facing eviction from land. Whiting [83] builds on this work to show that, while villagers in China appeal to distributive justice when they face reallocations within the village, they make additional procedural justice claims when they resist land takings by the state. Even for those rural land right holders who welcome land takings, justice claims center on the share of the full land value they receive and their place in the process [33]. Both Cui et al. [19] and Whiting [88] provide evidence that experience with grievances over land is negatively associated with trust in local government, an issue surprisingly understudied in democratic cases.

Ruparelia [60] and Andreas et al. [1] compare the role of law and courts in implementing land policy and adjudicating land rights in India and China, accentuating the authoritarianism of the Chinese case. "India's relatively independent judiciary provides some recourse to farmers to challenge their dispossession. While such challenges are rarely successful in stopping dispossession and have a demobilizing effect on movements, they are nevertheless often successful in increasing compensation and delaying projects-which can create time for other strategies to work in what is essentially a war of attrition ([1]:1126)." In China, law and legal mobilization are part of diverse strategies of "rightful resistance" [52]. Villagers' legal consciousness reflects in part the state's embrace of authoritarian rule by law [80] and the state's strategic responsiveness to petitioning [12,14, 21, 30]. At the same time, the Chinese state provides avenues of mediation, petitioning, and litigation to deter, atomize, and demobilize aggrieved citizens ([43]:1481, [80]). Moreover, "The invocation of coercive power is never too far from the realm of possibility (Lee and Zhang 2103:1491)." While Ruparelia ([60]:137), in comparing China and India, places analytical focus on steps the Modi administration has taken to limit the tools of activists seeking to protect farm households and prevent their dispossession, he concludes that "the scope for rights, law, and constitutionalism in India, despite mounting threats, is still far greater than in China."

Regime type matters in citizens' pursuit of land rights. China lacks party competition, organized groups fighting for land rights, and free media, which empower land-rights activists in India. The Chinese state controls legal institutions like courts and petition offices, limiting their role in resisting land grabs even as they help legitimize state actions. Notably, land protest is prominent in both cases but may be more successful in advancing the interests of aggrieved farmers in the Indian case.

\section{Land Rights and Social-Political Citizenship}

Part of China's “dual system (eryuan tizhi 二元体制)," land rights mark and entrench unequal citizenship for rural and urban residents. Land rights and household registration (hukou 户口) operate together to reinforce this divide. China 
scholars are beginning to put the Chinese case into comparative context, where land rights demarcate unequal citizenship in terms of race, caste, and gender. This section highlights the close relationship between unequal land rights, on the one hand, and incomplete social and political citizenship, on the other, where "social" refers to full access to economic welfare and security and "political" refers to full access to participation on the part of members of the community. This relationship holds across regime types and over time.

\section{Household Registration Status, Welfare, and Land Rights}

In an extension of the urban bias discussed above, the system of distinct urban and rural land rights is associated with unequal citizenship and welfare in China. Scholars have identified the ways in which the dual land system and the household registration (hukou 户口) system reinforce each other in shaping rural welfare [54, 67, 85, 89]. Yet Political scientists have uncritically accepted the Chinese state's claim that rural land-use rights provide a form of social welfare for rural citizens. Chen Xiwen [15], a leading official with responsibility for rural policy, states that "land is not only the "means of production' for farmers but also their social security. It is their safety net." With a focus specifically on rural-to-urban migrants in the reform era, Solinger [67] characterizes rural residents of China as second-class citizens; she also makes explicit the state's linkage between land and rural household registration status, invoking the official view that land-in the absence of urban welfare benefits - provides a form of social security and livelihood protection for rural residents ([67]:186-7). Wallace ([79]:176) similarly asserts that rural land provides a "social safety net" for rural migrants. Ong ([54]:164) echoes this view: "In the dualistic rural-urban structure in China, land serves as security for peasants in the same way that state-sponsored social welfare provides security for urban dwellers."

By contrast, I argue that the perpetuation of the land system provides a lever of power over rural households. The continued "rural" status of temporary migrant workers in urban areas empowers local governments to deny them urban benefits, like public housing and quality public education for their children and to remove them from urban areas in times of crisis, including the global financial crisis of 2008 and the covid-19 pandemic of 2020 (Chan 2010) [66]. Rather than provide unemployment, old-age, and health insurance to rural residents in the same system as urban residents, the state has invoked its granting of use-rights over small plots of collective land to rural households as a rationale to deny equal social welfare to rural residents and to rusticate them at the state's discretion.

The idea of rural land as social security has come under increasing scrutiny. The heavy tax-and-fee burden on farmers-up until the abolition of agricultural taxes and fees in 2004-undermined the role of land as livelihood protection and guarantee of subsistence [3]. As land takings for industrialization, urbanization, and infrastructure have increased in the home regions of migrant workers, the average land endowment of rural households has declined, further weakening any role of land as social security for rural residents [5]. The 2008 global financial crisis highlighted problems in reliance on rural hukou and land as a form of de 
facto unemployment insurance [42]. Younger returning migrant laborers lack the skills and experience to farm [13]. Older returning migrant laborers spur conflict when they demand the return of land they had rented out to other households [83]. In the context of land takings, Lee ([41]:205) characterizes rural migrant workers as doubly powerless, deprived of urban welfare and rural land.

Studies of land issues in China follow the ebb and flow of policy, at times losing the theoretical forest for the empirical trees. For example, experiments with land-for-welfare benefits (tudi huan baozhang 土地换保障) emerged as a new policy dynamic in the opening decades of the twenty-first century. This policy refers to the provision of more formal state welfare benefits to rural residents who lose their land [7, 31, 54]. However, even those rural residents who obtain urban household registration in compensation for their total loss of land receive only limited welfare benefits, perpetuating their second-class status [13]. Jiang et al. ([34]:1297) conclude that "even exemplary processes of providing compensation in the form of land for welfare and retained land use left expropriated people worse off." In 2014, policy makers ended the practice of converting rural to urban hukou and moved toward a more general type of residence permit. The state has effectively replaced hukou status with a strict hierarchy of urban places, which limits the ability of rural households to move to higher-tier cities where migrant workers are most likely to find jobs and where benefits are significantly better [13]. As of 2021, virtually all rural residents participate in rural pension and rural cooperative medical schemes. However, "actual financial benefit per person [is] very low and varie[s] across different regions ([16]:2)." In most cases, rural welfare benefits remain separate from and unequal to urban welfare benefits, and rural residents continue to experience second-class citizenship.

Thus, in the Chinese case, one important mode of exclusionary citizenship tied to land is rural vs. urban status. While some scholars see hukou status as operating in a separate and distinct manner from land rights [79], most scholars regard land rights and household registration status as mutually reinforcing legacies of the planned economy (World Bank [89]). The urban-rural divide has not been eliminated by hukou and land reforms. Indeed, Li et al. ([44]:148-9) find that the incomplete land rights of farm households help explain high levels of inequality.

\section{Gender and Land Rights}

Recent comparative scholarship highlights the intersection between women's status as citizens, political underrepresentation, and unequal property rights in land $[6,64,76]$. Andreas et al. [1] point out that in contemporary India, not only are women excluded from decision making but "the continued effective absence of women's land rights" means that women are excluded from compensation in the context of land takings. In China, Whiting [82] identifies multiple, conflicting sources of law-like authority governing land rights at the village level, which have the effect of weakening women's property rights and excluding them from land compensation and reallocation. 


\section{Exclusionary Modes of Land Rights and Citizenship}

Exclusionary land and citizenship rights are closely related in comparative analyzes of land grabbing [4], including diverse cases like US, South Africa, China, and India. Andreas et al. [1] compare land takings affecting rural residents of China with the dispossession impacting Dalit (lowest caste) and Adivasi (indigenous) communities in India. Lower caste and indigenous farmer are often landless; thus, disadvantaged communities in India may suffer more in the context of dispossession, since they typically hold even less of the bundle of property rights than do farmers in China. Notably, the authors argue that the greater off-farm opportunities that exist for rural migrants in China as compared to India's marginalized populations mitigate the worst effects of land dispossession for rural residents in China.

Cai et al. [9] introduce a comparison between China and the historical experience of the US. They emphasize differences rather than similarities in the historical evolution of land rights in the contemporary Chinese and US regimes; in doing so, they miss the exclusionary nature of land rights in the US. In China, property rights in land are "selective," because China's "discriminatory institutions... allow the state to expropriate land from millions of farmers for the benefit of others [9]:152)." By contrast, according to Cai et al. [9], in the US, property rights are a "public good." They see restrictions on property ownership for "Blacks, Native Americans, and women" as mere caveats rather than fundamental to the dynamics of the historical development of the US, with multi-generational distributional consequences [9]:152). At the same time, they adopt a teleological perspective on the US, which "marched toward providing property rights protection as a public good ([9]:152, emphasis added)." In broader historical perspective, similarities exist among exclusionary land and citizenship regimes. Cai et al. ignore an emerging critical literature on land rights in the US. Political scientist Frymer [22] establishes the decisive role of the federal and local governments in the US, which employed violence as well as law and courts to dispossess non-white populations of their land. Access to land and full citizenship are historically limited by race in the U.S. context [58]. Just as peasants were not the beneficiaries of China's peasant revolution, Blacks, Native Americans and women were not the beneficiaries of the American revolution. Land rights and citizenship are closely linked in both democratic and authoritarian, capitalist and post-socialist regimes, revealing and shaping who counts as a full member of the community.

\section{Conclusion}

This review highlights the relevance of the Chinese case for comparative theory in the context of global land grabbing. First, the Chinese case introduces nuance into the orthodox theory linking secure property rights and economic growth, and it answers questions in the literature about the nature and origins of urban bias. Second, while China's experience confirms the significance of non-democratic institutions in limiting the ability of ordinary citizens to shape policy, it highlights the key role of protest as a tool for citizens in both democratic and authoritarian regimes 
to capture a greater share of politically generated land rents. Finally, it reveals the links between the right to land and full citizenship across regime type and macrohistorical time. In sum, this review emphasizes the importance for China scholars to analyze China's land regime in comparative context, further developing the contribution to the discipline.

Acknowledgements The author thanks the editor and anonymous reviewers for their helpful suggestions.

\section{Declarations}

Conflicts of Interest There are no conflicts of interest to disclose.

\section{References}

1. Andreas, Joel, Sunila Kale, Michael Levien, and Qian Forrest Zhang. 2020. Rural land dispossession in China and India. Journal of Peasant Studies 47 (6): 1109-1142.

2. Bates, Robert. 1981. Markets and States in Tropical Africa. Los Angeles: University of California Press.

3. Bernstein, Thomas P., and Xiaobo Lü. 2000. Taxation without representation. China Quarterly 163: 742-763.

4. Boone, Catherine. 2007. Property and constitutional order. African Affairs 106 (425): 557-586.

5. Brandt, Loren, Susan Whiting, Linxiu Zhang, and Tonglong Zhang. 2017. Changing property rights regimes. China Quarterly 232: 1026-1049.

6. Brulé, Rachel E. 2020. Reform, representation, and resistance. Journal of Politics 82 (4): 1390-1405.

7. Cai, Meina. 2016. Land for Welfare in China. Land Use Policy 55: 1-12.

8. Cai, Meina, Jianyong Fan, Chunhui Ye, and Qi Zhang. 2021. Government debt, land financing, and distributive justice in China. Urban Studies 58 (11): 2329-2347.

9. Cai, Meina, Ilia Murtazashvili, and Jennifer Murtazashvili. 2020. The political of land property rights. Journal of Institutional Economics 16: 151-167.

10. Cai, Meina, and Xin Sun. 2018. Institutional bindingness, power structure, and land expropriation in China. World Development 109: 172-186.

11. Cai, Yongshun. 2003. Collective ownership or cadres' ownership? China Quarterly 175: 662-680.

12. Cai, Yongshun. 2010. Collective Resistance in China (Stanford: Stanford University Press).

13. Chan, Kam Wing. 2019. "China's hukou system at 60," Handbook on Urban Development in China. Edward Elgar Publishing pp. 59-79.

14. Chen, An. 2020. The impact of land requisition on peasant life in China. Modern China 46 (1): $79-110$.

15. Chen, Xiwen. 2014. Chinese Economists on Economic Reform. New York: Routledge.

16. Chen Y, Zhao L, Fan Y, Xie B. 2021. Does the new rural pension scheme improve residents' livelihoods? PLoS One 16(4).

17. Chuang, Julia. 2020. Beneath the China Boom. Berkeley: University of California Press.

18. Clarke, D., Peter Murrell, and Susan H. Whiting. 2008. "The role of law in China's economic development.” In Brandt and Rawski, eds., China's Great Economic Transformation. (Cambridge University Press).

19. Cui, Ernan, Ran Tao, Travis J. Warner, and Dali L. Yang. 2015. How do land takings affect political trust in rural China? Political Studies 63 (S1): 91-109.

20. Deng, Yanhua, and Kevin O'Brien. 2013. Relational repression in China. China Quarterly 215: 533-552.

21. Deng, Yanhua, Kevin O'Brien, and Li. Zhang. 2020. How grassroots cadres broker land taking in urbanizing China. Journal of Peasant Studies 47 (6): 1233-1250.

22. Frymer, Paul. 2011. Building an American empire, 1 U.C. Irvine L. Rev. 913. 
23. Gibson, James L. 2008. Group identities and theories of justice. Journal of Politics 70 (3): 700-716.

24. Gilley, Bruce. 2017. Taxation and authoritarian resilience. Journal of Contemporary China 26 (105): 452-464.

25. Göbel, Christian. 2021. Political logic of protest repression in China. Journal of Contemporary China 30 (128): 169-185.

26. Gong, Ting, and Wu. Muluan. 2012. The development of corruption in China from 2000 to 2009. Sociological Studies 4: 204-220.

27. Haber, Stephen. 2002. Crony Capitalism and Economic Growth in Latin America. Stanford: Hoover Institution Press.

28. Hall, Derek. 2013. Primitive accumulation, accumulation by dispossession and the global land grab. Third World Quarterly 34 (9): 1582-1604.

29. Han, Li., and James Kai-Sing. Kung. 2015. Fiscal incentives and policy choices of local governments. Journal of Development Economics 116: 89-104.

30. Heurlin, Christopher. 2016. Responsive Authoritarianism. New York: Cambridge University Press.

31. Heurlin, Christopher. 2019. Unemployment among land-losing farmers in China. Journal of Contemporary China 28 (117): 434-452.

32. Heurlin, Christopher. 2020. Fighting for every inch of land. Modern China 46 (4): 400-432.

33. Hsing, You-tien. 2010. The Great Urban Transformation. Oxford: Oxford University Press.

34. Jiang, Yanpeng, Sally Sargeson, and Luigi Tomba. 2020. No worse off? Journal of Peasant Studies 47 (6): 1278-1300.

35. Jones, Gareth A., and Stuart Corbridge. 2010. The continuing debate about urban bias. Progress in Development Studies 10 (1): 1-18.

36. Kan, Karita. 2020. The social politics of dispossession. Urban Studies 57 (16): 3331-3346.

37. Katznelson, Ira. 1993. Marxism and the City. Oxford: Oxford University Press.

38. Kennedy, John James. 2010. "The Price of Democracy," Asian Politics \& Policy Vol. 2, No. 4, pp. 617-631.

39. Kuang, Xianwen, and Christian Göbel. 2013. Sustaining collective action in urbanizing China. China Quarterly 216: 850-871.

40. Levien, Michael. 2018. Dispossession without Development. New York: Oxford University Press.

41. Lee, Ching Kwan. 2007. Against the Law (Berkeley: University of California Press).

42. Lee, Ching Kwan. 2016. Precarization or empowerment? Journal of Asian Studies 75 (2): 317-333.

43. Lee, Ching Kwan, and Yonghong Zhang. 2013. The power of instability. American Journal of Sociology 118 (6): 1475-1508.

44. Li, Shi, Terry Sicular, and Finn Tarp. 2021. "China," in Carlos Gradin et al., eds., Inequality in the Developing World (Oxford University Press), pp. 133-156.

45. Lipton, Michael. 1977. Why Poor People Stay Poor. Cambridge: Harvard University Press.

46. Looney, Kristen E. 2020. Mobilizing for Development. Ithaca: Cornell University Press.

47. Ma, Xiao, Susan H. Whiting, and Tan Zhao. 2017. "Vote Buying and Land Sales in China's Village Elections," American Political Science Association Annual Meeting, San Francisco.

48. Mattingly, Daniel C. 2016. Elite capture. World Politics 68 (3): 383-412.

49. Menaldo, Victor. 2016. "The Fiscal Roots of Urban Bias," Business \& Politics Vol. 18, No. 4, pp. 435-465.

50. Naughton, Barry. 1995. Growing out of the Plan. New York: Cambridge University Press.

51. North, Douglass. 1990. Institutions, Institutional Change, and Economic Performance. New York: Cambridge University Press.

52. O’Brien, Kevin, and Liangjiang Li. 2006. Rightful Resistance in Rural China. New York: Cambridge University Press.

53. Oi, Jean C. 1989. State and Peasant in Contemporary China. Berkeley: University of California Press.

54. Ong, Lynette. 2014. State-led urbanization in China. China Quarterly 217: 162-179.

55. Ong, Lynette H. 2020. Land grabbing in an autocracy and a multi-party democracy. Journal of Contemporary Asia 50 (3): 361-379.

56. Pei, Minxin. 2016. China's Crony Capitalism. Cambridge: Harvard University Press.

57. Peng, Chun. 2018. Rural Land Takings in Modern China. New York: Cambridge University Press.

58. Rana, Aziz. 2010. Two Faces of American Freedom. Cambridge: Harvard University Press.

59. Rithmire, Meg E. 2015. Land Bargains and Chinese Capitalism. New York: Cambridge University Press.

60. Ruparelia, Sanjay. 2018. "Contesting the right to law," in Prasenjit Duara and Elizabeth Perry, eds. 2018. Beyond Regimes (Cambridge: Harvard University Asia Center), pp. 99-142. 
61. Sargeson, Sally. 2013. Violence as development. Journal of Peasant Studies 40 (6): 1063-1085.

62. Sargeson, Sally. 2016. Review of Rithmire, Land Bargains and Chinese Capitalism. China Journal 76: 167-169.

63. Sargeson, Sally. 2018. Grounds for self-government. Journal of Peasant Studies 45 (2): 321-346.

64. Sargeson, Sally, and Yu. Song. 2010. Land expropriation and the gender politics of citizenship in the urban frontier. China Journal 64: 19-45.

65. Shih, Victor. 2010. "Local government debt." China Economic Quarterly (June) pp. 26-32.

66. Shih, Victor. 2021. China's Leninist response to COVID-19. In Coronavirus Politics, ed. Scott L. Greer, et al., 67-85. Ann Arbor: University of Michigan Press.

67. Solinger, Dorothy. 1999. Contesting Citizenship in Urban China. Berkeley: University of California Press.

68. Sorace, Christian, and William Hurst. 2016. China's phantom urbanisation and the pathology of ghost cities. Journal of Contemporary Asia 46 (2): 304-322.

69. Su, Fubing, Ran Tao, and Hui Wang. 2013. "State Fragmentation and Rights Contestation," China \& World Economy Vol. 21, No. 4, pp. 136-55.

70. Su, Fubing, and Ran Tao. 2017. The China model withering? Urban Studies 54 (1): 230-250.

71. Sun, Xin. 2015. Selective enforcement of land regulations. China Journal 74: 66-90.

72. Tang, Yongfeng, and Isabelle Côté. 2021. How large-scale land protests succeed in China. Journal of Chinese Political Science 26: 333-352.

73. Tao, Ran, Su. Fubing, Mingxing Liu, and Guangzhong Cao. 2010. Land leasing and local public finance in China's regional development. Urban Studies 47 (10): 2217-2236.

74. Trappel, René. 2011. Agrarian change in China. In Politics and Markets in Rural China, ed. Björn. Alpermann, 15-29. New York: Routledge.

75. Trappel, René. 2021. From peasant to elite. China Perspectives 2: 9-18.

76. Tripp, Aili Mari. 2004. "Women's Movements, Customary Law and Land Rights in Africa," African Studies Quarterly Vol. 7, No. 4, pp. 1-19.

77. Tsai, Lily. 2007. Solidary groups, informal accountability, and local public goods provision in rural China. American Political Science Review 101 (2): 55-372.

78. Tsui, Kai Yuen. 2011. China's infrastructure investment boom and local debt crisis. Eurasian Geography and Economics 52 (5): 686-711.

79. Wallace, Jeremy L. 2014. Cities and Stability. New York: Oxford University Press.

80. Whiting, Susan H. 2017. "Authoritarian 'Rule of Law' and Regime Legitimacy," Comparative Political Studies Vol. 50, No. 14, pp. 1907-1940.

81. Whiting, Susan H. 2010a. "Fiscal reform and land public finance," in Joyce Man and Yu-Hung Hong, eds., China's Local Public Finance in Transition (Lincoln Institute of Land Policy), pp. 125-144.

82. Whiting, Susan H. 2010b. "What's Law Got to Do with It?" EAI Fellows Program Working Paper \#25, pp. 1-17.

83. Whiting, Susan H. 2011. "Values in Land," Urban Studies Vol. 48, No. 3 (February), pp. 569-587.

84. Whiting, Susan H. 2016. Review of Wallace, Cities and Stability, and World Bank, Urban China. China Journal 75: 206-209.

85. Whiting, Susan H. 2019. Review of Peng, Rural Land Takings Law in Modern China. China Quarterly 237: 263-264.

86. Whiting, Susan H. 2021. Washington Post Monkey Cage. https://www.washingtonpost.com/politics/ 2021/10/21/chinas-evergrande-is-trouble-so-is-chinas-top-down-political-economy/

87. Whiting, Susan H., Daniel Abramson, Shang Yuan, and Stevan Harrell. 2019. A long view of resilience in the Chengdu Plain, China. Journal of Asian Studies 78 (2): 257-284.

88. Whiting, Susan H. Illiberal Law and Development Cambridge University Press (under contract).

89. World Bank and Development Research Center of the State Council. 2014. Urban China. Washington, DC: World Bank Publications.

90. Yew, Chiew Ping. 2012. Pseudo-urbanization? Journal of Contemporary China 21 (74): 281-298.

91. Zhan, Shaohua. 2019. Accumulation by and without dispossession. Journal of Agrarian Change 19 (3): 447-464.

92. Zhang, Changdong. 2021. Governing and Ruling. Ann Arbor: University of Michigan Press.

93. Zhao, Tan. 2018. Vote buying and land takings in China's village elections. Journal of Contemporary China 27 (110): 277-294.

Susan Whiting is Professor of Political Science at the University of Washington. 